\title{
Management of severe preeclampsia in the puerperium: development and scenario validation for clinical simulation
}

\author{
Manejo de pré-eclampsia grave no puerpério: validação de cenário para simulação clínica \\ Manejo de la preeclampsia severa en el puerperio: validación de escenarios para simulación clínica
}

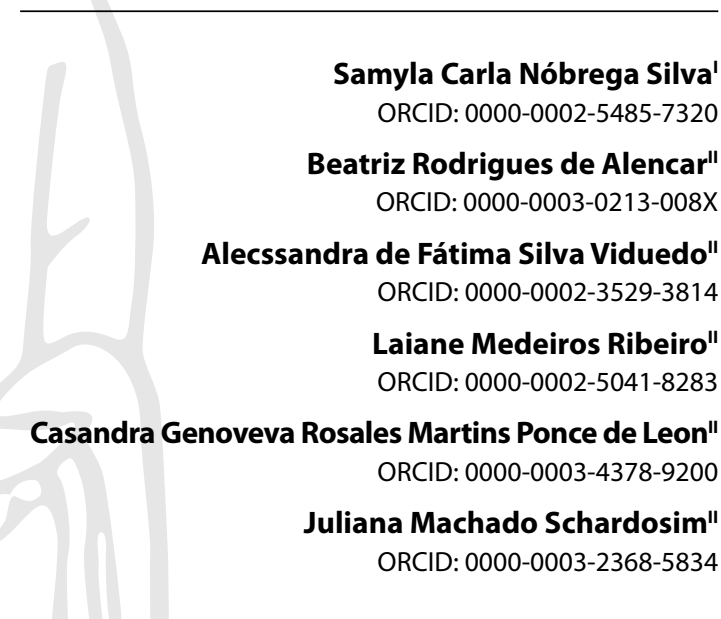

Secretaria Estadual de Saúde do Distrito Federal, Programa de Residência Multiprofissional. Brasília, Distrito Federal, Brazil. "Universidade de Brasília, Faculdade de Ceilândia. Brasília, Distrito Federal, Brazil.

How to cite this article: Silva SCN, Alencar BR, Viduedo AFS, Ribeiro LM, Ponce de Leon CGRM, Schardosim JM. Management of severe preeclampsia in the puerperium: development and scenario validation for clinical simulation.

Rev Bras Enferm. 2021;74(6):e20200445. https://doi.org/10.1590/0034-7167-2020-0445

\section{Corresponding author:}

Juliana Machado Schardosim E-mail: jumachadoju@hotmail.com

EDITOR IN CHIEF: Antonio José De Almeida Filho ASSOCIATE EDITOR: Ana Fátima Fernandes

Submission: $07-13-2020$

Approval: 12-09-2020

\section{ABSTRACT}

Objective: to develop and validate a scenario for clinical simulation in nursing education on the management of severe preeclampsia in the puerperium. Method: methodological study in five stages (overview, scenario, scenario design progression, debriefing and assessment), developed from March to December 2019, involving 10 volunteers (one professor, five actors and four judges). Data were analyzed using descriptive statistics and Content Validation Index. Results: the scenario was built from the definition of learning objectives that meet the needs of nursing education. From the completion of a Likert scale, by the judges in on-site validation, a Content Validity Index of 1.0 was reached, which indicates $100 \%$ agreement in the assessed items. Conclusion: the scenario was validated. It is expected that teaching by simulation will be expanded and that new studies of scenario validation will contribute to the preparation of future nurses, based on the most recent scientific evidence.

Descriptors: Simulation Training; Education, Nursing; Obstetric Nursing; Pre Eclampsia; Validation Studies.

\section{RESUMO}

Objetivo: desenvolver e validar um cenário para simulação clínica no ensino de enfermagem sobre manejo da pré-eclâmpsia grave no puerpério. Método: estudo metodológico em cinco etapas (overview, scenario, scenario design progression, debriefing e assessment), desenvolvido de março a dezembro de 2019, envolvendo 10 voluntários (uma professora, cinco atores e quatro juízes). Dados foram analisados por estatística descritiva e Índice de Validação de Conteúdo. Resultados: construiu-se o cenário partindo da definição de objetivos de aprendizagem que atendem às necessidades de ensino de enfermagem. A partir do preenchimento de uma escala Likert pelos juízes na validação in loco, chegou-se a um Índice de Validade de Conteúdo de 1,0, que indica $100 \%$ de concordância nos itens avaliados. Conclusão: o cenário elaborado foi validado. Espera-se que o ensino por simulação seja expandido e que novos estudos de validação de cenários contribuam para o preparo de futuros enfermeiros, com embasamento das evidências científicas mais recentes.

Descritores: Treinamento por Simulação; Educação em Enfermagem; Enfermagem Obstétrica; Pré-Eclâmpsia; Estudos de Validação.

\section{RESUMEN}

Objetivo: desarrollar y validar un escenario de simulación clínica en la educación de enfermería sobre el manejo de la preeclampsia severa en el puerperio. Método: estudio metodológico en cinco etapas (overview, scenario, scenario design progression, debriefing y assessment), desarrollado de marzo a diciembre de 2019, con la participación de 10 voluntarios (un docente, cinco actores y cuatro jueces). Los datos se analizaron mediante estadística descriptiva e índice de validación de contenido. Resultados: el escenario se construyó a partir de la definición de objetivos de aprendizaje que respondan a las necesidades de la formación en enfermería. A partir de la cumplimentación de una escala Likert por parte de los jueces en la validación presencial, se alcanzó un Índice de Validez de Contenido de 1.0, lo que indica un 100\% de concordancia en los ítems evaluados. Conclusión: el escenario fue validado. Se espera que la enseñanza de la simulación se amplíe y que los nuevos estudios de validación de escenarios contribuyan a la preparación de los futuros enfermeros, basados en la evidencia científica más reciente.

Descriptores: Entrenamiento por Simulação; Educación en Enfermería; Enfermería Obstétrica; Preeclampsia; Estudios de Validación. 


\section{INTRODUCTION}

Gestational hypertensive syndromes are one of the main causes of maternal morbidity and mortality in the world and in Brazil, in addition to causing significant fetal complications such as prematurity, restricted intrauterine growth and even intrauterine fetal death ${ }^{(1)}$. According to the clinical picture evolution, blood pressure changes in pregnancy can be classified as gestational hypertension (when there is only increased blood pressure), preeclampsia (when there is proteinuria associated with hypertension), eclampsia (when seizures occur), HELLP syndrome (when there are changes in liver and coagulation tests), and preeclampsia superimposed on chronic hypertension (when there is proteinuria or other changes in pregnancy of a chronic hypertensive woman). The puerperium represents a delicate period that requires a lot of attention from the health team that assists these mothers, as there may still be worsening of hypertension, seizures and other clinical changes such as coagulation problems ${ }^{(2-3)}$.

Due to the impacts on maternal and child health and the complexity of this pathology, it is necessary the availability of professionals prepared for proper management at all levels of care. Nurses, as a professional qualified to monitor prenatal care for habitual risk and attention to childbirth and the puerperium, need to be prepared to recognize and properly refer the pregnant woman to follow-up in a specialized prenatal service. In childbirth and puerperium, nurses, as leaders of the nursing team, plan and conduct nursing care to keep the patient stable and with minimal associated repercussions ${ }^{(4)}$.

In order to offer qualified professionals to the job market, nursing education has evolved a lot since the profession began. In its emergence as a modern profession, nursing ended up facing issues related to medical subordination in the work environments; at the end of the $19^{\text {th }}$ century and the beginning of the $20^{\text {th }}$ century, teaching was guided by the observation and repetition of students in relation to professionals who work. Since the 1980s, nursing courses have become better structured and understand students as people in the process of building knowledge, in which critical and constructive attitudes towards reality are expected ${ }^{(5)}$.

Currently, there is a great highlight of active teaching methodologies, which have as their central element students' role in their teaching-learning process. Among these, simulation stands out as an innovative method that has been increasingly inserted in several undergraduate courses, especially in health care professions $^{(6)}$. It is found that students learn best when they practice in controlled/simulated environments and when they actively participate in learning practices. The simulated environment allows students to repeat the task numerous times without causing harm to another person; thus, the academic is more confident in the actual practice environments ${ }^{(7)}$.

Simulation aims to replace or expand real experiences, presenting itself as an attempt to reproduce the essential aspects of a clinical scenario so that when a similar scenario occurs in a real context, the situation can be successfully managed by the team ${ }^{(8)}$. To build scenarios that are increasingly coherent with the reality of students, it is essential to validate them for use in simulation, because it is from the validation that the real implementation of the clinical case is analyzed in students' training process and in their training as a future nurse to react in similar situations.
In the validation process of judges and/or target audience, all stages of scenario elaboration are assessed to ensure that it has integrity, reproducibility and is aligned with the recommended standards for the construction of the clinical simulation scenario and with the updated scientific evidence ${ }^{(9)}$. This assessment can occur with the reproduction of the scenario in the presence of evaluators (judges and/or target audience), called on-site validation $^{(10)}$, or distance, with the use of the Delphi technique ${ }^{(9)}$.

Considering the above, the relevant study is considered because it contributes to the applicability of these innovative teaching methodologies in nursing and contributes to the future nurses being qualified for early detection of gestational hypertensive syndromes and capable of the elaboration and implementation of a care plan for stabilization of these pregnant women and puerperal women.

\section{OBJECTIVE}

To develop and validate a scenario for clinical simulation in nursing education on the management of severe preeclampsia in the puerperium.

\section{METHODS}

\section{Ethical aspects}

The study was approved by the Research Ethics Committee of the university in which it was developed, respecting the standards of the Brazilian National Health Council (Conselho Nacional de Saúde), Resolution 466/12 $2^{(11)}$. Participants accepted it by signing the Informed Consent Form and the Image and Sound Use Authorization Term.

\section{Study design, period, and location}

This is a methodological study, which adopted the five stages described by Guilbert and Adamson (2016) ${ }^{(12)}$ : overview, scenario, scenario design progression, debriefing and assessment.

The study was developed from March to December 2019, from research planning to on-site validation, which took place on November 20, 2019 at the Laboratory of Skills and Simulation in the Care of a public university in Brasilia. Validation lasted an average of 75 minutes (5 minutes of pre-briefing, 20 minutes of briefing, 10 minutes of debriefing and about 10 minutes for each judge to make his questions and comments about the preparation of the scenario and debriefing's checklist).

To write this article, the SQUIRE 2.0 assumptions of the Equator network were considered.

\section{Population, inclusion and exclusion criteria}

To perform on-site validation, it took 10 volunteers, one professor, five actors (two participating as students to be inserted in the scenario and three in the roles provided for in the scenario) and four professionals in the roles of judges. The professor was the guide of this study; actors were students of a nursing course of the university in which the study was developed; the judges were professionals with knowledge about the theme of the scenario.

For students, the approval of the comprehensive care of women's and children's health of the nursing course of the public university 
in which the study was developed was considered an inclusion criterion was considered inclusion criteria. The choice of judges considered a minimum of 4 points according to the Judge Scoring System, adapted from Góes et al $(2014)^{(13)}$, which included aspects related to training, professional experience and scientific production. Each item scored from 1 to 2 points, with a sum for each judge. For the selection of judges, the Lattes Platform was used to search for researchers from the Federal District who met the inclusion criteria. Subsequently, contact was made with those selected by e-mail.

For students, there were no exclusion criteria. For the judges, it was considered an exclusion criterion that professionals occupy positions that did not allow their direct clinical practice for 2 years or more, as it is understood that recent scientific updates might not be known to professionals, impairing their assessment of the simulated scenario.

\section{Study protocol}

The study protocol followed the five steps proposed by the methodological framework adopted ${ }^{(12)}$. The theoretical framework for the construction of the case was based on manuals from the Ministry of Health of Brazil, technical notes, scientific articles and updated books, with an exhaustive reading on the topic of hypertensive syndromes in pregnancy and the role of nurses in detection, management and control of these pathologies. Such materials were made available to students who would participate in the scenarios, acting as puerperal woman and companion, for prior study.

In the first stage, called overview, a reflection was carried out on the items that would be worked on in the scenario, defining the learning objectives. Other details such as content and references that would be important for students to study before being inserted in the scenario were also defined.

The second stage, called scenario, consisted in the construction of the clinical case, based on scientific evidence. At that moment, only the details of the clinical case were defined and what information would be exposed to students in the pre-briefing (moment before the scenario in which students can recognize the environment starts), at the time of the realistic simulation.

In the third stage, called scenario design progression, the entire event plan of the scenario was elaborated, aiming to meet the objectives proposed in step 1. The event plan includes the definition of necessary roles/actors, the writing of scripts for all roles and the definition of all material elements necessary for setting up the scenario.

The fourth stage, called debriefing, consisted of the elaboration of a checklist with technical items on the subject for assessment of students inserted in this scenario. In simulation teaching, debriefing is the most important step in promoting student-professor dialogue and identifying positive aspects and those that could be improved by students. For this moment to be fluid, it is important that the instrument that will guide the professor's assessment is well elaborated and systematic, favoring a directed and impartial assessment by the professor. The elaboration of the checklist also aims to meet the objectives proposed for the scenario.

After the previous steps, with the scenario and the checklist elaborated, the fifth stage called assessment was carried out. This stage consisted of the validation of the scenario (on-site validation) through the judges' assessment of the scenario presented and all the documents produced in each stage. In order for the judges to be able to visualize the applicability of the scenario in nursing teaching, the clinical simulation was performed with all stages (pre-briefing, briefing and debriefing). At the end of this activity, each judge was able to make a verbal and written assessment of the scenario in addition to the checklist for debriefing proposed by the researchers.

\section{Data analysis}

The data were analyzed in Microsoft Excel software spreadsheets ${ }^{\circ}$, version 2016 . For the validation of the scenario, Content Validation Index (CVI) was calculated. CVI is a measure of the agreement of judges on the topics assessed on the elaborated scenario. CVI calculation was based on the completion of a Likert scale with 4 response alternatives (Totally inadequate; Inadequate, but can be redone; Adequate, with small adjustments; Fully adequate), the latter two being considered for validation purposes. The minimum acceptable CVI value for scenario validation was 1.0 , following the literature recommendation for a body of six judges or less ${ }^{(14)}$.

\section{RESULTS}

From the analysis of training and experience of judges in the Lattes Platform, according to the criteria adopted, the scores obtained ranged from 7 to 16 points. Of the four judges, only one was male. The judges' profile is shown in Table 1. It is observed that, although young professionals with relatively little experience time, all have some post-graduation title, are professors and use simulation in nursing teaching. Some had contact with simulation as students (in graduation); nowadays, they have enough experience to understand the perspective of students and professor in the use of the scenario in the validation process.

Table 1 - Characterization of the study judges, Brasília, Federal District, Brazil

\begin{tabular}{|c|c|c|}
\hline & $\mathbf{n}$ & $\%$ \\
\hline Age (years)* & $27.25 \pm 0.96$ & \\
\hline $\begin{array}{l}\text { Academic background } \\
\text { Nursing degree }\end{array}$ & 4 & 100 \\
\hline $\begin{array}{l}\text { Graduate degrees } \\
\text { Specialization } \\
\text { Master's degree } \\
\text { Doctoral degree }\end{array}$ & $\begin{array}{l}2 \\
2 \\
0\end{array}$ & $\begin{array}{l}50 \\
50 \\
00\end{array}$ \\
\hline $\begin{array}{l}\text { Professional activity } \\
\text { Assistance } \\
\text { Professors } \\
\text { Graduate student }\end{array}$ & $\begin{array}{l}1 \\
4 \\
3\end{array}$ & $\begin{array}{c}25 \\
100 \\
75\end{array}$ \\
\hline Time of experience (years) & $4.75 \pm 1.5$ & \\
\hline $\begin{array}{l}\text { Experience with simulation } \\
\text { Professor } \\
\text { Researcher } \\
\text { Participation as a judge previously }\end{array}$ & $\begin{array}{l}4 \\
2 \\
3\end{array}$ & $\begin{array}{c}100 \\
50 \\
75\end{array}$ \\
\hline Time of experience with simulation§ & $2.5(2.0-3.75)$ & \\
\hline Publications in women's health & 2 & 50 \\
\hline Publications on realistic simulation & 1 & 25 \\
\hline
\end{tabular}


The validation of the scenario occurred by calculating CVI. Starting from a Likert scale, completed by the judges on the day of on-site validation, considering the two response alternatives that indicated the assessed aspect as adequate, a CVI of 1.0 was reached. This value indicates that the judges agreed with $100 \%$ of the items assessed. The assessed aspects were the same as in the study by Ponce de Leon et al (2018) ${ }^{(11)}$. From these records, CVI was calculus, as shown in Table 2.

After completing the assessment instrument, the judges had 10 minutes to verbally explain their assessment and score suggestions for improvements for the items that scored "Adequate, with small adjustments". All the suggestions given by the judges were incorporated into the scenario and debriefing's checklist, namely: explicit description that the newborn has already been assessed, avoiding that students lack time for the conducts related to preeclampsia; recommendation to leave calcium gluconate easy to access, as it acts as a magnesium sulfate antagonist $\left(\mathrm{MgSO}_{4}\right)$; recommendation to leave the infusion pump on or with the infusion parameters of the drug clearly exposed in the pump; recommendation that the professor make available the vital signs sheet so that students can have clinical reasoning before the case. Chart 1 summarizes the main information about the validated scenario.

In the checklist proposed for the debriefing, topics on assistance to the puerperal women under observation by management of gestational hypertension and using magnesium sulfate were included, such as assessment of laboratory tests, the performance of guidelines for the puerperal woman and the companion regarding the warning signs, the need to avoid excessive stimuli in the environment. Chart 2 presents the proposed checklist for the debriefing of this scenario.

Table 2 - Assessment of judges on the clinical case "Nursing performance in the face of severe preeclampsia in the puerperium", Brasília, Federal District, Brazil

\begin{tabular}{|c|c|c|c|c|c|c|c|c|c|}
\hline \multirow[t]{2}{*}{ Rated Items } & \multicolumn{2}{|c|}{$\begin{array}{c}\text { Totally } \\
\text { Inadequate }\end{array}$} & \multicolumn{2}{|c|}{$\begin{array}{l}\text { Inadequate, } \\
\text { but can be } \\
\text { redone }\end{array}$} & \multicolumn{2}{|c|}{$\begin{array}{c}\text { Adequate, } \\
\text { with small } \\
\text { adjustments }\end{array}$} & \multicolumn{2}{|c|}{$\begin{array}{c}\text { Totally } \\
\text { adequate }\end{array}$} & \multirow[t]{2}{*}{ CVI } \\
\hline & $\mathbf{n}$ & $\%$ & $\mathbf{n}$ & $\%$ & n & $\%$ & $\mathbf{n}$ & $\%$ & \\
\hline Plausibility of the clinical case & - & - & - & - & - & - & 4 & 100 & 1.0 \\
\hline Realism & - & - & - & - & 1 & 25 & 3 & 75 & 1.0 \\
\hline Adherence to available scientific evidence & - & - & - & - & 1 & 25 & 3 & 75 & 1.0 \\
\hline Complexity in relation to the level of knowledge and students' skills & - & - & - & - & - & - & 4 & 100 & 1.0 \\
\hline Case description & - & - & - & - & 2 & 50 & 2 & 50 & 1.0 \\
\hline Simulation objectives provided to students & - & - & - & - & 2 & 50 & 2 & 50 & 1.0 \\
\hline Information provided to students prior to simulation & - & - & - & - & - & - & 4 & 100 & 1.0 \\
\hline Data provided to students during 9 simulation & - & - & - & - & - & - & 4 & 100 & 1.0 \\
\hline Support provided to students during simulation & - & - & - & - & 1 & 25 & 3 & 75 & 1.0 \\
\hline Learning objectives & - & - & - & - & - & - & 4 & 100 & 1.0 \\
\hline Critical thinking promotion & - & - & - & - & 1 & 25 & 3 & 75 & 1.0 \\
\hline Promoting the ability to prioritize nursing assessments and interventions & - & - & - & - & - & - & 4 & 100 & 1.0 \\
\hline Promoting autonomous problem-solving & - & - & - & - & - & - & 4 & 100 & 1.0 \\
\hline Simulator/actress parameters consistent with clinical case & - & - & - & - & - & - & 4 & 100 & 1.0 \\
\hline Simulated environment & - & - & - & - & 1 & 25 & 3 & 75 & 1.0 \\
\hline Materials and equipment available to students & - & - & - & - & 1 & 25 & 3 & 75 & 1.0 \\
\hline Aspects assessed in debriefing & - & - & - & - & 2 & 50 & 2 & 50 & 1.0 \\
\hline Reflection and analysis of actions in debriefing & - & - & - & - & 1 & 25 & 3 & 75 & 1.0 \\
\hline Synthesis and feedback to students in debriefing & - & - & - & - & 2 & 50 & 2 & 50 & 1.0 \\
\hline Mean CVI & & & & & & & & & 1.0 \\
\hline
\end{tabular}

Chart 1 - Description of the validated scenario on nurses' performance in the face of severe preeclampsia in the puerperium, Brasília, Federal District, Brazil

Subject addressed: nurse's performance in the face of severe preeclampsia in the puerperium

\begin{tabular}{|l|l}
\hline Complexity: medium & Fidelity: high
\end{tabular}

Expected scenario execution time: up to 30 minutes

Number of students inserted in the scenario: 2 students

Simulated environment: hospital obstetric center

Learning objective: to assess students' knowledge about routine care in the face of gestational hypertension in the puerperium, as well as their attitude towards the puerperal woman and companion.

Brief description of the clinical case:

J.S.A., 36 years old, postpartum woman with newborn still in the obstetric center, 6 hours postpartum normal, accompanied by her husband. Second-inlaw with 2 previous vaginal deliveries and no history of abortion. Gestational age: 38 weeks and 4 days, newborn adequate for gestational age. Puerperal women arrived at the hospital on the day of delivery with hypertensive crisis, being diagnosed with severe preeclampsia after the severity tests. She started magnesium sulfate hours before delivery and continues to sulfate, according to protocol. The last assessment of the parameters related to the infusion of the medication was made 4 hours ago. The baby has already been assessed by the nurse from the previous shift and by the pediatrician. 
Scripts: the scenario starts with the puerperal woman and her baby in the obstetric center. The nurse of the previous shift begins the shift and delivers the patient's medical records to students.

Nurse: good morning, this is Janaína, is 36 years old, is her second baby. Now it's okay, but she's had severe preeclampsia and she's sulfating. The baby was born well and has already been assessed by me and the pediatrician, the puerperium is going well so far. She's already had a bath. Good call for you.

Students are expected to observe the puerperal woman's medical records in order to better understand their clinical picture. Check the medication you're running and talk to the couple about everything that happened, and then assess the postpartum. If students talk about pregnancy, the puerperal woman will answer:

Puerperal woman: in pregnancy, my pressure has changed since 7 months and I took the medicine right. Then, on the day of delivery, I came here feeling very ill, I thought it was because of the pain, but my blood pressure was too high and they said it was preeclampsia. After they started this medication in the vein, I got better. They just didn't tell me how long I'm going to have to stay here with this serum.

If students talk about how the patient feels in the puerperium:

Puerperal woman: I'm feeling good, the pressure is still not very normal, but it has already improved a lot. I've showered and felt good, l eat. The baby breastfeeds well and sleeps well.

If students talk about breastfeeding history:

Puerperal woman: I had a little difficulty in the first few days, but I managed to breastfeed my daughter until 2 years. Mamou only in the chest up to 6 months. Students are expected to take a full physical examination in the postpartum period, noting:

Hypocorated, anicteric and acyanotic skin and mucous membranes. Venous access in salinized right upper limb and access in left upper limb infusing magnesium sulfate with $5 \%$ glucose serum in $100 \mathrm{ml} / \mathrm{h}$ infusion pump. Flaccid breasts, protracted nipples, with colostrum output to expression. Flaccid abdomen, painless on palpation, Pinard safety globe at the height of the umbilical scar. Perineum intact, red lochias in physiological quantity. Diuresis in a collection bag of the long-delayed bladder probe ( $200 \mathrm{ml})$, had been emptied for 4 hours. She hasn't evacuated after childbirth yet. Swollen lower limbs $3+/ 4+$, no signs of thrombosis (Homans, Brancroft and Flag negative). Vital signs: Blood Pressure: $140 \mathrm{mmHg}$, Heart Rate: 89bpm, Respiratory Rate:19irpm, Axillary Temperature: $36.5^{\circ} \mathrm{C}$. Because students have 4 hours of the last assessment of the effects of the medication, students are expected to check blood pressure, respiratory rate, diuresis and patellar reflexes. If they assess and do not explain the reason for assessment, the companion may ask:

Companion: why does anyone review all this again from time to time? Is it because of her pressure?

If they take a physical examination and test the newborn's reflexes, everything will be within normal limits. Because it is a mannequin, the professor will answer what is necessary. Students will receive the medical records of puerperal woman where there will be the evolutions of labor, delivery and immediate postpartum and the medical prescription according to the protocol of management of severe preeclampsia in the puerperium. Moreover, the professor should prepare a sheet containing the vital signs of the puerperal woman compatible with the described scenario.

If students do not explain to the couple about the evolution of gestational hypertension in the puerperium and the therapeutic plan, they may question students. Below are some speech suggestions:

Companion: and how long will she stay here? The family is very curious to visit and meet the baby. Several mothers who have won baby after her have already gone to rooming-in.

Puerperal woman: why am I with this probe? It doesn't hurt, but it bothers me, can we take it off?

Puerperal woman: when will my pressure normalize? How do I know if I've had high blood pressure forever or if it's really going to pass?

\section{Materials required for simulated environment assembly:}

- Furniture and decoration: items of hospital furniture such as stretcher with sheets, procedure table, table with medical-hospital materials to simulate nursing station, telephone, screen, contaminant garbage and common garbage, small staircase, common acrylic cradle, serum support, posters (topics such as labor and breastfeeding) and identification of the patient in bed, as other materials that can be added.

- Medical-hospital materials: sphygmomanometer, stethoscope, axillary thermometer, reflex test hammering, personal protective equipment (gloves, caps and masks), cotton, $70 \%$ alcohol, aluminum trays, syringes, needles and jelcos of various sizes and calibers, cutting-hole disposal box, infusion pump, simple serum equipment and for infusion pump, multi-way, $500 \mathrm{ml}$ saline $0.9 \%$ vial and $500 \mathrm{ml}$ glucose serum vial $0.5 \%$, distilled water, medication ampoules (simulating magnesium sulfate; and other medications commonly used in the obstetric center), micropore/adhesive and garrote.

- Medical records and other documents: pregnant woman's booklet with information about prenatal care, obstetric center care form, medical and nursing evolutions of labor, medical prescriptions and vital signs control sheet.

Simulators/mannequins, costumes and makeup of the actors:

- Simulators/mannequins: newborn simulator and silicone breast model for physical examination

- Costume: puerperal woman (hospital sweater, legging and leather-colored blouse, perineal lining and postpartum absorbent with scenographic blood or red paint), companion (common clothing of choice of the actor, avoid shorts), nurse (surgical clothing, closed shoe, cap and identification badge)

- Makeup: the case does not require specific makeup, it is only suggested that the puerperal woman be made up with a little dark circles and pallor to give appearance of tiredness.

Chart 2 - Checklist of skills and knowledge expected of students, Brasília, Federal District, Brazil

\begin{tabular}{|c|c|c|c|c|c|}
\hline & Skills and knowledge expected from students & NP & $\mathbf{I}$ & PA & A \\
\hline \multirow{6}{*}{ 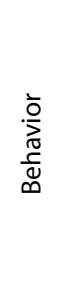 } & They presented themselves to the puerperal woman and companion. & & & & \\
\hline & They welcomed the puerperal woman and companion. & & & & \\
\hline & They explained each procedure before starting. & & & & \\
\hline & They provided a privacy environment for the patient and companion (use of screen, curtains or private room). & & & & \\
\hline & They presented effective communication with the other professionals of the scenario. & & & & \\
\hline & They presented work organization (choice of leader, division of tasks as a team). & & & & \\
\hline \multirow{5}{*}{ 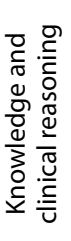 } & They remembered to research a history of pressure change in pregnancy and other alterations related to gestational hypertension. & & & & \\
\hline & They demonstrated knowledge about the evolution of gestational hypertension in the puerperium. & & & & \\
\hline & Demonstrated knowledge about the $\mathrm{MgSO}_{\text {administration protocol }}$ in the puerperium & . & & & \\
\hline & They demonstrated knowledge about the test results. & & & & \\
\hline & They demonstrated knowledge about actions to avoid stimulus and raise pressure. & & & & \\
\hline
\end{tabular}




\begin{tabular}{|c|c|c|c|c|c|}
\hline & Skills and knowledge expected from students & NP & $\mathbf{I}$ & PA & A \\
\hline \multirow{7}{*}{ 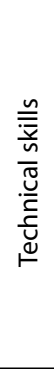 } & They performed hand washing/antisepsis before direct contact with the pregnant woman. & & & & \\
\hline & Performed all procedures with correct use of personal protective equipment. & & & & \\
\hline & They verified complete vital signs (heart rate, respiratory rate, axillary temperature, blood pressure). & & & & \\
\hline & They underwent cephalocaudal physical examination. & & & & \\
\hline & $\begin{array}{l}\text { They performed gynecological assessment (breast examination, palpation of pinard safety globe, perineal inspection, lochia } \\
\text { assessment). }\end{array}$ & & & & \\
\hline & The lower limbs were assessed (edema and other alterations). & & & & \\
\hline & The parameters related to magnesium sulfate impregnation (respiratory rate, diuresis volume, patellar reflex) were assessed. & & & & \\
\hline \multirow{2}{*}{ 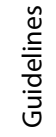 } & They guided on the evolution of gestational hypertension in the puerperium and care for pressure control. & & & & \\
\hline & $\begin{array}{l}\text { They guided on routine puerperal care (feeding, water intake, uterine involution, perineal hygiene, breastfeeding and return to } \\
\text { the Basic Health Unit). }\end{array}$ & & & & \\
\hline
\end{tabular}

Note: NP: Not Performed; I: Inadequate; PA: Partially Adequate; A: Adequate.

\section{DISCUSSION}

Hypertensive syndromes are among the three main causes of maternal mortality according to the Pan American Health Organization and the World Health Organization ${ }^{(1)}$. As it is a disease considered severe and causing hospitalizations in Intensive Care Units, an in-depth knowledge of professionals who are involved in the care of affected pregnant women is required.

Due to the impacts on maternal and child health and the complexity of this pathology, it is necessary the availability of professionals prepared for proper management at all levels of care $^{(4)}$. Hence the importance of preparing nurses since graduation. However, to promote safe nursing care and positive outcomes for patients, it is important and essential that nursing educators identify strategies to cultivate and improve the clinical reasoning skills of nursing students ${ }^{(15)}$. Simulation provides a safe environment for the improvement of these skills as future nurses ${ }^{(16)}$. In a systematic review with the objective of knowing the impact of educational interventions on nursing students to develop their communication skills with patients, simulation was described in 11 of the 19 studies found. Based on the main findings, it can be indicated that most of the analyzed studies used simulation as a methodology for the training of communication skills, obtaining statistical significance in the results ${ }^{(17)}$.

Simulation is described in literature as an important strategy in relation to training nurses in case of refusal of family members for the vaccine ${ }^{(18)}$; neonatal resuscitation ${ }^{(19)}$; on medication errors ${ }^{(20)}$, among others. But in relation to the validation of scenarios, it is still a little studied area, especially in relation to women's health and obstetrics. We found only one study on scenario validation on the management of postpartum hemorrhage ${ }^{(9)}$ and a study on scenario validation in the care of a pregnant adolescent ${ }^{(10)}$.

From the structuring of simulation as a scientifically based teaching method, the validation of the scenarios created by experts in the area emerged. Validation ensures the integrity, reproducibility, and alignment of the scenario with the recommended ${ }^{(9)}$ standards. In the validation, the judges are invited to perform assessment of the scenario and the debriefing instrument. There is no consensus on the recommended number of judges; however, literature recommends that the body of judges be in an odd amount and not less than three ${ }^{(14)}$. These judges are experts in the studied area, and, precisely due to expertise, the options become somewhat restricted, in addition to the need to reconcile the agendas of researchers, actors and judges to perform validation. As detailed in Table 1, the panel of judges in this study was composed of teaching professionals, with postgraduate and experience in obstetrics or with simulation in nursing teaching. Thus, it is believed that the judges were able to analyze the theoretical content of the scenario, as well as the research method used to construct and validate the scenario and its applicability/reproducibility for use in nursing teaching.

For validation, it is necessary to construct the scenario based on the learning objectives listed, based on updated scientific evidence on the theme that will be addressed, and each stage of the process must be documented so that judges and educational institutions that adopt the scenario have access to ${ }^{(10)}$. The validation of the scenarios provides for several stages of elaboration that give rigor to the elaboration of the scenario. In these steps, the details that make up the scenario (objectives, roadmap, human resources, and materials) are defined. All details about the scenario validated in this study are in Chart 1. Researchers also recommend that validation should be filmed for future analysis ${ }^{(21)}$, as was conducted in this study.

The mathematical calculation used in validation studies is CVI, which reflects the agreement among judges. It is observed the adoption of different parameters regarding the minimum value of CVI to consider the validated scenario. A theoretical article on the subject suggests different ranges of values according to the number of judges included in the study. For six judges or less, it is suggested that CVI of 1.0 be sought, which reflects $100 \%$ agreement in the judges' assessment ${ }^{(14)}$. This was the parameter adopted and achieved in this study.

A study that validated scenarios for teaching in maternal-infant nursing with the same number of judges adopted the parameter of 0.75 and obtained CVI of 0.81 in their scenarios ${ }^{(10)}$. Another study, which validated a scenario on postpartum hemorrhage under assessment by judges and students, determined 0.80 as the minimum value for CVI, having obtained 0.90 in assessment of judges and 0.95 in assessment of students ${ }^{(9)}$.

Despite CVI 1.0 obtained in this validation study, small adjustments were made in attention to aspects scored as "Adequate, with small adjustments". It is noteworthy, however, that some 
of these aspects correspond to the execution of the case and do not impact on the reproducibility of this scenario in other institutions, namely: learning objectives provided to students, support provided to students during simulation, reflection and analysis of actions in debriefing and synthesis and feedback to students of the debriefing. These questions correspond to the way in which the professor positioned herself at the time of the execution of the scenario on the day of on-site validation and not to the content elaborated and described in the scenario. The judges considered that considering the theoretical material, more information could have been provided to students.

\section{Study limitations}

Because only researchers, students and judges from the Federal District are involved, it is believed that these scenarios may not correspond to the reality of other localities. However, the essence of the scenario can be developed with adapted environments. If the institution that is interested in using this scenario does not have any described material, it can also adapt. As for the debriefing's checklist, it is considered that it is adapted to any form adapted recreated to the scenario because it corresponds to essential aspects to the solution of this clinical case specifically, provided that the essence of the clinical case does not change. As it is a local study, the number of judges was reduced due to the fact that few researchers met the selection criteria.

\section{Contributions to nursing, health, and public policies}

Nursing has evolved a lot since the days of Florence Nightingale, including her teaching strategies. Active methodologies have been encouraged in recent decades because they are student-centered and rely on dynamic strategies that arouse students' interest in seeking and deepening their knowledge. Clinical simulation has gained space in scientific publications, especially validation studies of scenarios that have begun to be produced more recently. However, studies related to nursing practice in obstetrics are still scarce.

The validated scenarios are elaborated and analyzed by the judges; therefore, they transmit more security to the professor who wishes to develop a simulated activity. It is considered that this study can contribute to nursing teaching and, thus, to preparation of future nurses in coping and managing situations of severe preeclampsia. Due to the severity of the event and its frequency in the population, not always all students have the opportunity of real experience during graduation, being able to work this theme with the simulated activities.

\section{CONCLUSION}

After the study is complete, it is concluded that the proposed objective of elaborating and validating a scenario for nursing simulation in the management of severe preeclampsia in the puerperium was achieved, with CVI of 1.0. The suggestions for improvement proposed by the judges were fundamental for the scenario to be more faithful to reality, the dialogue between the research team and the body of judges was of great growth for this study.

The publication of validated scenarios of great importance is considered, since realistic simulation has been widely used in health education, especially in nursing, and that the validation process gives scientific rigor to the scenario. It is expected, with this study, to give more visibility to scenario validation and realistic simulation as a teaching method and also to stimulate other researchers to take the initiative to validate and publish their scenarios so that we can work, in academia, always with validated scenarios.

Finally, it is also expected that this scenario will contribute to the training of future nurses in relation to the detection and management of hypertensive syndromes during pregnancy, since these professionals work at all levels of gestational care from prenatal care to the puerperium.

\section{FUNDING}

The study received financial support from CNPq through a grant awarded in a notice of the Scientific Initiation Program in Technological Development and Innovation (PIBITI - Programa de Iniciação Científica em Desenvolvimento Tecnológico e Inovação) 2019-2020 of Universidade de Brasília.

\section{ACKNOWLEDGMENTS}

We thank all students and judges who opportunistized the development of this study.

\section{REFERENCES}

1. Organização Pan-Americana de Saúde (OPAS). Folha Informativa-Mortalidade Materna [Internet]. 2018 [cited 2020 Apr 08]. Available from: https://www.paho.org/bra/index.php?option=com_content\&view=article\&id=5741:folha-informativa-mortalidade-materna\&ltemid=820

2. Secretaria Estadual de Saúde do Distrito Federal (SESDF). Síndromes Hipertensivas na Gestação - Manejo na Emergência. Protocolos de Atenção à Saúde[Internet]. 2018[cited 2020 Apr 10]. Available from: http://www.saude.df.gov.br/wp-conteudo/uploads/2018/04/10.S\%C3\%ADndromes-Hipertensivas-na-Gesta\%C3\%A7\%C3\%A30-\%E2\%80\%93-Manejo-na-Emerg\%C3\%AAncia.pdf

3. Ministério da Saúde (BR). Secretaria de atenção à saúde. Departamento de atenção básica. Atenção ao pré-natal de baixo risco. Cadernos de Atenção Básica, n. 32 [Internet]. Brasília: Editora do Ministério da Saúde. 2012 [cited 2020 Apr 10]. Available from: http://bvsms.saude.gov. br/bvs/publicacoes/cadernos_atencao_basica_32_prenatal.pdf

4. Leite VC, Gasquez AS, Bertoncim KR. [Stratification of risk in persons in prenatal]. Rev Uningá [Internet]. 2019 [cited 2020 Apr 19];56(S2):18493. Available from: http://revista.uninga.br/index.php/uninga/article/view/2160/1912. Portuguese 
5. Serra MN. Learning to be a nurse: professional identity in nursing students. Sisifo: Educ Scienc J [Internet]. 2016 [cited 2020 Mar 27];5:69-80. Available from: http://sisifo.ie.ulisboa.pt/index.php/sisifo/article/view/93/148

6. Martins JCA. Aprendizagem e desenvolvimento em contexto de prática simulada. Rev Enferm Ref. 2017;IV(12):155-62. https://doi. org/10.12707/RIV16074

7. Uysal N. Melhoria dos resultados de aprendizagem de alunos de enfermagem através da capacitação baseada em cenários. Rev Latino-Am Enfermagem. 2016;24:e2790. https://doi.org/10.1590/1518-8345

8. Abreu AG, Freitas JS, Berte M, Ogradowski KRP, Nestor A. O uso da simulação realística como metodologia de ensino e aprendizagem para as equipes de enfermagem de um hospital infanto-juvenil: relato de experiência. Rev Ciênc Saúde [Internet]. 2014 [cited 2020 Apr 18];7(3):162-6. Available from: http://revistaseletronicas.pucrs.br/ojs/index.php/faenfi/article/view/17874/12495

9. Andrade PON, Oliveira SC, Morais SCRN, Guedes TG, Melo GP, Linhares FMP. Validation of a clinical simulation setting in the management of postpartum haemorrhage. Rev Bras Enferm. 2019;72(3):656-663. https://doi.org/10.1590/0034-7167-2018-0065

10. Ponce de Leon CGRM, Silva AK, Ribeiro LM, Brasil GC, Guarda LEA, Fonseca LMM. Development and validation of clinical cases to be used in maternal-child nursing education. Rev Enferm Ref. 2018;4(18):51-62. https://doi.org/10.12707/RIV18013

11. Conselho Nacional de Saúde. Resolução $n^{\circ} 466,2012$. Diretrizes e Normas regulamentadoras de pesquisa envolvendo seres humanos [Internet]. Brasília, Junho, seção 1, p. 59, 2012[cited 2020 Apr 10]. Available from: https://conselho.saude.gov.br/resolucoes/2012/Reso466.pdf

12. Guilbert M, Adamson KA. Making sense of methods and measurement: validation part Il. Clin Simul Nurs. 2016;12(7):275-6. https://doi. org/10.1016/j.ecns.2016.02.006

13. Góes FSN, Dalci MCB, Fonseca LMM, Canini SRMS, Scochi CGS. Desenvolvimento de casos clínicos para o ensino do raciocínio diagnóstico. Rev Eletr Enferm. 2014;16(1):44-51. https://doi.org/10.5216/ree.v16i1.20564

14. Alexandre NMC, Coluci MZO. Validade de conteúdo nos processos de construção e adaptação de instrumentos de medida. Ciênc Saúde Coletiva. 2011;16(7):3061-8. https://doi.org/10.1590/S1413-81232011000800006

15. Powers K. Bringing simulation to the classroom using an unfolding video patient scenario: a quasi-experimental study to examine student satisfaction, self-confidence, and perceptions of simulation design. Nurse Educ Today. 2020;86(104324). https://doi.org/10.1016/j. nedt.2019.104324

16. Davies H, Schultz R, Sundin D, Jacob E. 'Ward for the day': a case study of extended immersive ward-based simulation. Nurse Educ Today. 2020;10(90):104430. https://doi.org/10.1016/j.nedt.2020.104430

17. Gutiérrez-Puertas L, Márquez-Hernández VV, Gutiérrez-Puertas V, Granados-Gámez G, Aguilera-Manrique G. Educational interventions for nursing students to develop communication skills with patients: a systematic review. Int J Environ Res Public Health. 2020;17(2241):1-21. https://doi.org/10.3390/ijerph17072241

18. Nold L, Deem MJ. A Simulation experience for preparing nurses to address refusal of childhood vaccines. J Nurs Educ. 2020;59(4):222-6. https://doi.org/10.3928/01484834-20200323-09

19. Garvey AA, Dempsey EM. Simulation in neonatal resuscitation. front pediatr. 2020;8(59):1-10. https://doi.org/10.3389/fped.2020.00059

20. Kuo SY, Wu JC, Chen HW, Chen CJ, Hu SH. Comparison of the effects of simulation training and problem-based scenarios on the improvement of graduating nursing students to speak up about medication errors: a quasi-experimental study. Nurse Educ Today. 2020;87(104359). https://doi.org/10.1016/j.nedt.2020.104359

21. Fabri RP, Mazzo A, Martins JCA, Fonseca AS, Pedersoli CE, Miranda FBG, et al. Construção de um roteiro teórico-prático para simulação clínica. Rev Esc Enferm USP. 2017;51:e03218. https://doi.org/10.1590/S1980-220X2016016403218 